\title{
Efficacy and safety of Ketoprofen Gel treatment in patients with low back pain
}

\author{
For citation: Bol', sustavy, pozvonočnik. 2021;11(1):28-34. doi: 10.22141/2224-1507.11.1.2021.226906
}

\begin{abstract}
Background. The purpose was to study the effectiveness and safety of Ketoprofen gel (Fastum gel) therapy in patients with low back pain (LBP) caused by degenerative-dystrophic changes of the spine. Materials and methods. 24 males and females aged 50-69 years with LBP lasting over 14 days were examined, with a further division into two groups. Group I - 12 patients received thin ketoprofen applications on the lumbar region 2 times a day for 10 days. Group II - 12 patients who received thin applications of Vaseline on the same area 2 times a day for 10 days. Patients used the study drugs as a monotherapy. Examination was performed before the treatment initiation, after 10 and 20 days of treatment. Results. Patients receiving ketoprofen applications had a significantly reduced pain intensity registered by all four components of VAS and the Roland-Morris questionnaire. At the same time, the functional capacity by Schober $(t=3.54, p=0.005)$ and Tomayer $(t=3.08, p=0.01)$ tests was significantly improved. The quality of life according to the EuroQul-5D scale in patients who used the topical ketoprofen significantly increased by $45 \%(\mathrm{t}=4.19, \mathrm{p}=0.002)$, and life expectancy according to the Oswestry questionnaire by $39.3 \%$ after 10 days of treatment $(t=3.9, p=0.002) .75 \%$ of patients from the main group and $33.3 \%$ from the comparison group assessed the effectiveness of treatment as high according to the Likert index. Neither group reported localized nor systemic side effects. Conclusions. Monotherapy of ketoprofen gel significantly reduced the intensity of pain and improved the functional capacity of patients with LBP. The absence of side effects during treatment indicates its high safety profile for patients.
\end{abstract}

Keywords: low back pain; topical form; ketoprofen gel

\section{Introduction}

The low back pain (LBP) is localized between the lower $12^{\text {th }}$ rib pair and horizontal gluteal crease [1], and is usually attended by pain in one or two legs [2]. According to some researchers, the LBP is one of the most ancient diseases occurring as early as the human being starting to walk [3].

The low back pain is a very common symptom affecting all the age groups - from children to the elderly people [3]. It is attended by a significant restriction of patient's activity and has a negative effect on the quality of their everyday life [4]. The low back pain is not usually followed by disability, and disappears in most patients during 14 days [5]. The LBP is widely-spread across the world: in high-, moderate-, and low-income countries [2]. It causes a lot of significant healthcare and disabilityrelated spendings [3], and exceeds costs of cardiovascular, cancer and diabetes care [6]. If the acute low back pain turns chronic, it may become a serious medical and socio-economic issue [5].
The success of LBP treatment depends on identification of its causes and selection of treatment tactics [5]. The range of etiological factors is rather wide. The LBP may be both a short-term clinical manifestation, and a first symptom of serious sacroiliac pathologies; in $5 \%$ cases, it requires an emergency care (oncology, metastatic spinal injuries, damages, infectious lesions etc.) [3]. In 4 $\%$ cases, the LBP is caused by vertebral fractures [7]; in $5-10 \%$ cases, it is associated with spinal nerve root injury (due to intervertebral disc hernia, spinal stenosis or cauda equina syndrome (CES)). Bedsides the above-mentioned causes, the LBP is attributed to the pain irradiating from the pelvis minor (endometriosis, tumors, ovarian cysts, prostate hypertrophy), urinary diseases (urolithiasis) [3, 5]. However, in most (80-90\%) cases, the LBP results from the mechanic and static influence on the spine and adjacent structures [3]. The treatment is aimed at the pain syndrome intensity reduction.

According the modern recommendations on the anamnesis collection and physical examination of the LBP

C) 2021. The Authors. This is an open access article under the terms of the Creative Commons Attribution 4.0 International License, CC BY, which allows others to freely distribute the published article, with the obligatory reference to the authors of original works and original publication in this journal.

Для кореспонденції: Поворознюк Владислав Володимирович, доктор медичних наук, професор, завідувач відділу клінічної фізіології та патології опорно-рухового апарату, дУ «Інститут геронтології ім. Д.Ф. Чеботарьова НАМН України», вул. Вишгородська, 67, м. Київ, 04114, Україна; e-mail: okfpodac@ukr.net

For correspondence: Vladyslav Povoroznyuk, MD, PhD, Professor, Head of the Department of clinical physiology and pathology of musculo-skeletal system, State Institution “D.F. Chebotarev Institute of Gerontology by the NAMS of Ukraine", Vyshgorodska st., 67, Kyiv, 04114, Ukraine; e-mail: okfpodac@ukr.net

Full list of authors information is available at the end of the article. 
patients, one should check for the "red flags" or warning signals of the graver principal pathology [7]. Their lists may differ, though among the common characteristics there are: age under 20 or over 50 years, sternum pain, nighttime pains, pain at rest, weight loss, neurological disorders involving multiple dermatomes, progressive motor deficiency, disability, a history of oncological diseases, injuries, immunodeficiency, a long-term glucocorticoid use $[5,7]$.

If there are no "red flag" symptoms, the first-line medications are Acetaminophen and Non-Steroidal Anti-Inflammatory Drugs (NSAIDs) [8, 9]. Among the NSAIDs, the best safety profile is reserved for the topical forms (gels, creams, plasters, sprays), the fact attributed to the absent systemic effect. The mechanism of these medications is based on the anti-inflammatory action, as well as cutaneous nerve ending stimulation [10].

The study is aimed at exploring the efficacy and safety of Ketoprofen gel (Fastum gel) for the low back pain patients suffering from the degenerative-dystrophic spinal changes.

\section{Materials and methods}

The clinical study is performed according to the limited programme, being open, controlled, parallel randomized comparative trial. It follows the requirements by the State Pharmacological Center by the Ministry of Health of Ukraine for the restricted clinical trials and approved by the Ethical Committee of the State Institution "D.F. Chebotaryov Institute of Gerontology by the NAMS of Ukraine" (of 17.12.2020, protocol № 35/20).

Following the detailed explanation of participation entry pre-requisites and study of "The Patient's informative leaflet", the participants were signing the written agreement to the participation.

The key medication used in the trial was Ketoprofen gel ( $1 \mathrm{~g}$ of gel contains $0.025 \mathrm{~g}$ of ketoprofen) produced by A. Menarini Manufacturing Logistics and Services, S.r.L. (Menarini Group). Besides ketoprofen, the medication has the following active ingredients: Carbomer 940, Ethanol 96\%, neroli oil, lavandin essential oil (fragrance), triethanolamine and purified water. The Carbomer 940 is a unique gel medium ensuring a powerful transdermal transporting effect, bringing ketoprofen to the deeply injured sites. The neroli oil provides an antiseptic, spasmolytic, anesthetic and calming effect. The lavandin essential oil has an anti-inflammatory and antiseptic effect. The triethanolamine is a low-molecular oil emulsifier, ensuring an optimal $\mathrm{pH}$ rate and intensifying the penetrating ketoprofen properties.

\section{Characteristics of the examined patients}

The trial was held at the Department of Clinical Physiology and Pathology of Locomotor Apparatus, the State Institution "D.F. Chebotaryov Institute of Gerontology by the NAMS of Ukraine". It involved 24 male and female subjects aged 50-69 years, suffering from the LBP lasting over 14 days and attended by the degenerative-dystrophic spinal changes. The patients were divided into two groups:
Group I was made of 12 patients treated by thin ketoprofen applications on lumbar site twice a day during 10 days; Group II was made of 12 patients treated by thin petroleum jelly applications on the same site twice a day during 10 days. The LBP patients were using the tested medication as a monotherapy. At the moment of trial entry, the patients were not taking any NSAIDs during 2 weeks or glucocorticoids during 4 weeks. The diagnosis was based on the LBP patients' complaints (pain intensity $>40 \mathrm{~mm}$ by VAS), clinical and X-ray data (confirmed degenerative-dystrophic spinal changes).

Among the exclusion criteria, there were pains of another genesis, a known hypersensitivity to the ketoprofen, its metabolites and/or any other component, as well as allergic response to any NSAIDs in the past; acute ulcerative gastric or intestinal disease, gastrointestinal bleeding or perforation; acute or grave heart failure; hepatic or renal function disorders.

\section{Study methods}

The pain syndrome was evaluated by means of a 4-item Visual Analogue Scale (VAS) and the "Roland-Morris Low Back Pain and Disability Questionnaire" (M. Roland, R. Morris, 1983) three times: before the initiation of therapy, after 10 and 20 days of treatment. The 4-item VAS has 4 questions: VAS1: "How intense is the pain at the moment?", VAS2: "What is your most typical or mean pain rate?", VAS3: "What is your pain rate at the best period of disease (how close to 0)?", VAS4: "What is your pain rate at the worst period of disease (how close to 10)?". In order to evaluate the spinal pathology attributed life expectancy, one used the Oswestry Disability Index (1980). The disease-related patient's self-evaluation was studied by the Likert Scale, the life quality by EuroQol5D. The spinal mobility was studied by the side bending (to the right and to the left), Tomayer and Schober test.

The clinical trials, anthropometrical measurements (height, body weight, body mass index) and functional tests were performed before the therapy initiation, after 10 and 20 days of treatment.

The tolerance and safety evaluation was made by means of outside factor and response control based on the subjective symptoms and sensations, objective findings.

The statistical analysis was made by means of Statistika 10.0. In order to perform statistical analysis, we used Student t-test for the independent and paired samples. The findings are presented as $M \pm S D$, where $M$ is a mean value, SD - standard deviation. The results were considered reliable if $\mathrm{p}<0.05$.

\section{Results}

At the beginning of the trial, there were no registered differences among the groups in terms of age and anthropometric data (Fig.1).

Prior to the therapy initiation, in the group of patients treated with ketoprofen applications, 6 subjects (50\%) registered the highest pain intensity rate (from 7 to 10 points) by VAS scale, 6 subjects $(50 \%)$ registered a moderate pain intensity rate, namely at the examination time 
(4 to 6 points). At the "worst period of the disease", the highest pain intensity rate (from 7 to 10 points) was registered by 11 subjects $(91.7 \%)$, the moderate pain intensity rate (from 4 to 6 points) was registered by 1 subject ( 8.3 $\%)$. Prior to the therapy initiation, in the reference group, 4 subjects $(33.3 \%)$ reported the highest pain intensity rate (from 7 to 10 points) by VAS scale "at the moment", while 8 subjects $(66.7 \%)$ reported the moderate pain intensity rate (from 4 to 6 points). At the "worst period of the disease", the highest pain intensity rate (from 7 to 10 points) was reported by 9 subjects $(75 \%)$ and the moderate pain intensity rate (from 4 to 6 points) was reported by 3 subjects $(25 \%)$.

After the 10 days of ketoprofen treatment, there was a confirmed reduction of pain intensity syndrome according by the 4-item VAS scale: "at the moment" by $47.4 \%$ $(\mathrm{t}=5.29, \mathrm{p}=0.001)$, "the moderate pain intensity rate" by $26.1 \%(\mathrm{t}=3.46, \mathrm{p}=0.005)$, "pain at the best period of the disease" by $29.0 \%(\mathrm{t}=2.55, \mathrm{p}=0.03)$, "pain at the worst period of the disease" by $24.0 \%(\mathrm{t}=3.13, \mathrm{p}=0.01)$ (Fig.1 A). In the reference group, there was a significant reduction of pain intensity rate only by the VAS scale "at the moment" by $24.0 \%(\mathrm{t}=2.88, \mathrm{p}=0.01)$ and at the "worst period of the disease" by $14.4 \%(\mathrm{t}=4.31$, $\mathrm{p}=0.001)$. The changes were not registered in "the moderate pain intensity rate" and "pain at the best period of the disease" items after 10 and 20 days of observation (Fig. 1B).

The group of patients treated with ketoprofen applications reported a significant reduction of pain syndrome intensity by the VAS data and Roland-Morris Question- naire. In the ketoprofen group, the reduction was by 41.0 $\%$ after 10 days of treatment, while in the reference group, only by $5.1 \%$ (Fig. 2).

After the treatment, the patients of main group were receiving the ketoprofen. They reported a significant improvement of life expectancy by the Oswestry Disability Index (39.3\% after 10 days of treatment $(t=3.9$, $\mathrm{p}=0.002)$. In the reference group, the dynamics of this parameter was only $9.0 \%(t=5.2, p=0.0003)($ Fig. 3$)$.

According to the EuroQol-5D scale, the significant differences of life quality values were registered only in the group of patients receiving the ketoprofen treatment after 10 and 20 days (Fig. 4).

Within the principal group, there is a significant improvement of fingertip-to-floor (FTF) test results: increase by $44.5 \%(t=3.08, p=0.01)$. For instance, before the ketoprofen therapy initiation, the distance from the three (middle) fingertips to the floor at the maximum forward tilt (Tomayer test) is $11.4 \pm 9.3 \mathrm{~cm}$, while 10 days after the treatment initiation the distance is $6.3 \pm 7.4 \mathrm{~cm}$ (Fig. 5A), and 20 days after the treatment initiation the distance is $6.4 \pm 8.2 \mathrm{~cm}$ (Fig. 4B).

Following the treatment, one has observed a significant improvement of locomotor apparatus mobility by the Schober test results $(t=-3.54, p=0.005)$. In the group of patients treated with ketoprofen applications, there was a more pronounced dynamic after 10 days of treatment. The distance between two points increased from $13.8 \pm 0.4 \mathrm{~cm}$ to $14.5 \pm 0.5 \mathrm{~cm}$, while in the reference group there were no significant differences (Fig.5). There are signs of side-to-side spinal mobility improvement by

Table 1. Anthropometric characteristics of the examined subjects

\begin{tabular}{|l|c|c|c|c|}
\hline \multicolumn{1}{|c|}{ Parameter } & Group I & Group II & t \\
\hline Age, years & $59.7 \pm 6.1$ & $62.4 \pm 6.5$ & 1.0 & 0.3 \\
\hline Weight, kg & $77.8 \pm 14.7$ & $74.4 \pm 8.0$ & 0.7 & 1.5 \\
\hline Height, cm & $165.7 \pm 10.1$ & $160.6 \pm 5.9$ & 0.1 \\
\hline Body mass index, IU & $28.3 \pm 4.6$ & $28.9 \pm 3.4$ & 0.4 \\
\hline
\end{tabular}

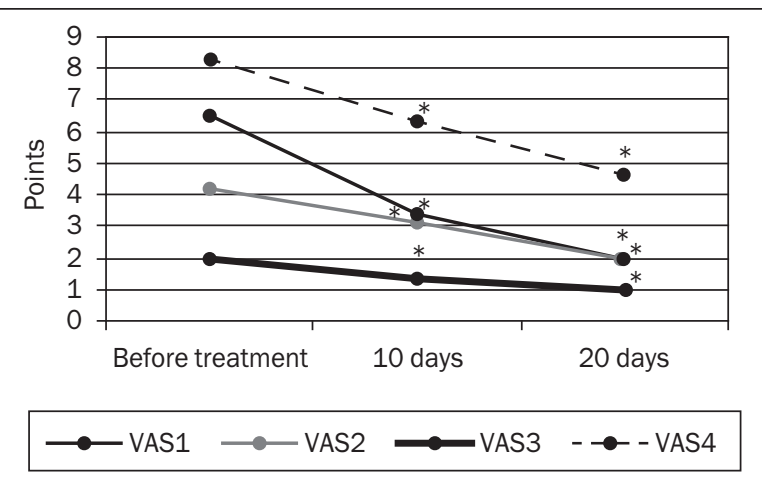

A

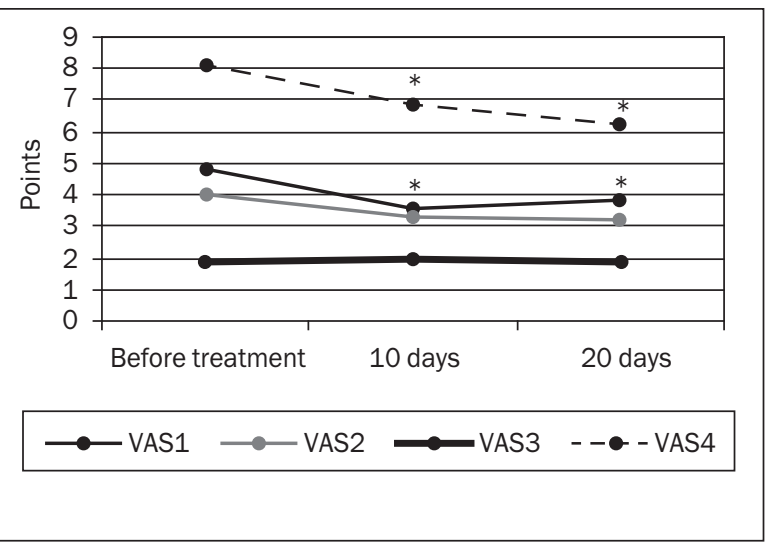

Fig.1. The pain syndrome intensity by the 4-item Visual Analogue Scale on the treatment background: (A) - ketoprofen group (B) - reference group

Notes: * $-p<0.05$ compared to the initial values. 
the right-to-left bending test $(\mathrm{t}=-3.92, \mathrm{p}=0.002$ and $\mathrm{t}=-3.44, \mathrm{p}=0.005)$.

Ketoprofen's safety and tolerance. While surveying the ketoprofen-treated patients, we haven't registered any localized (site irritation, skin dryness, reddening, itching, edema) or systemic (headache, dyspepsia, diarrhea, drowsiness, allergic reaction) adverse effects. Using the Likert Scale, the patients have evaluated the treatment effect as high ( $75 \%$ of principal group, $33.3 \%$ of reference group).

\section{Discussion}

The principal purpose of LBP treatment is the pain intensity reduction and functional activity improvement [11]. According to our findings, the ketoprofen gel use promotes a significant improvement of functional test performance by $44.5 \%$, according to the Tomayer $(\mathrm{t}=3.08, \mathrm{p}=0.01))$ and Schober tests $(\mathrm{t}=3.54$, $\mathrm{p}=0.005$ ). Furthermore, we have registered a significant improvement of spinal mobility according to the rightto-left bending test $(\mathrm{t}=3.92, \mathrm{p}=0.002$ and $\mathrm{t}=3.44$, $\mathrm{p}=0.005)$. Moreover, one has observed a pain syndrome intensity reduction, according to the VAS pain scale, after 10 days of ketoprofen treatment, considering all 4 items: "at the moment" $(\mathrm{t}=5.29, \mathrm{p}=0.001)$, "the moderate pain intensity rate" $(\mathrm{t}=3.46, \mathrm{p}=0.005)$, "pain

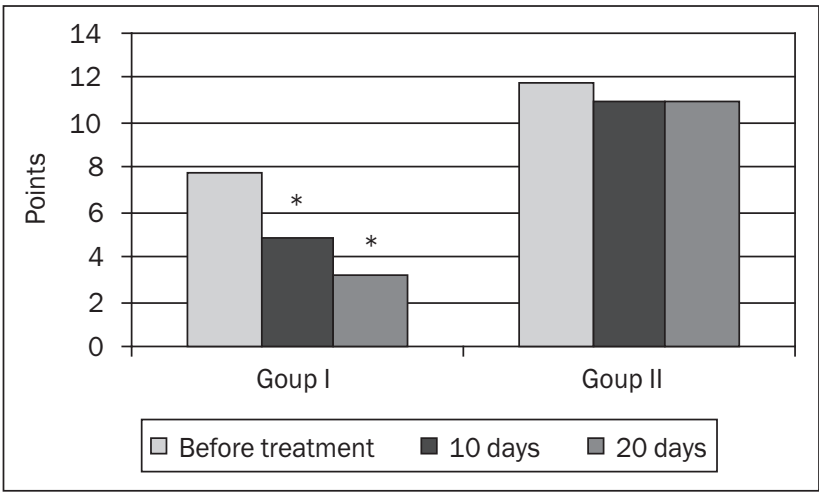

Fig.2. The pain syndrome intensity

by the Roland-Morris Questionnaire on the ketoprofen treatment background

Notes: ${ }^{*}-p<0.05$ compared to the initial values.

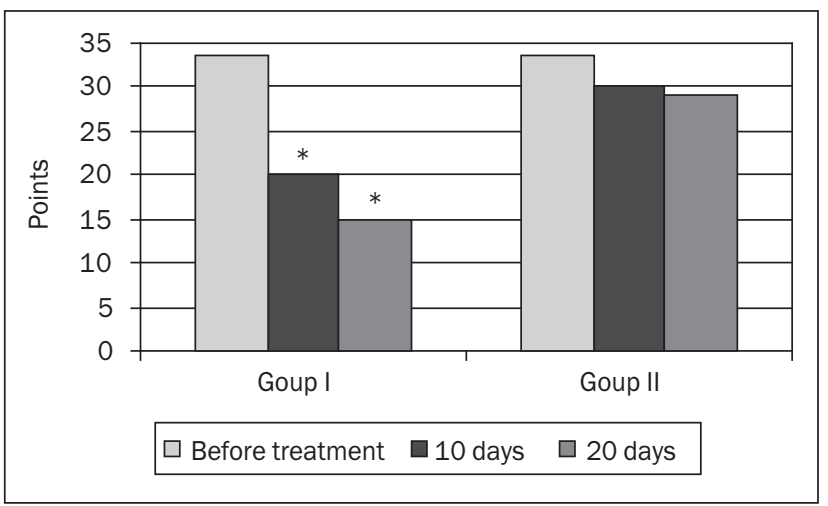

Fig. 3. Level of function by the Oswestry Disability Index on the ketoprofen treatment background

Notes: $*-p<0.05$ compared to the initial values. at the best period of the disease" $(\mathrm{t}=2.55, \mathrm{p}=0.03)$ and "pain at the worst period of the disease" $(\mathrm{t}=3.13$, $\mathrm{p}=0.01)$. In the group of patients treated with ketoprofen applications, there was a significant reduction of pain syndrome intensity, according to the Roland-Morris Low Back Pain and Disability Questionnaire, by $41.0 \%$ after 10 days of treatment. In the reference group, this reduction was registered by $5.1 \%$.

The "Pain in Europe" study demonstrates the effect of pain syndrome on the life quality and psychoemotional condition: $13 \%$ of the surveyed patients had to retire due to pain, $19 \%$ lost their jobs, $21 \%$ were diagnosed with depression, over $40 \%$ reported a feeling of helplessness and a failure to interpret the reality or to function properly [12]. The NSAIDs are the most effective medications in terms of spine and joint pain treatment [6]. Our analysis of the EuroQol-5D scale findings, the Group I reported a significant improvement of the following parameters: walking, self-care, everyday activity, pain intensity and depression, by $45 \%$ $(\mathrm{t}=4.19, \mathrm{p}=0.002)$. We have also received a considerable improvement of functional activity by $39.3 \%$ after 10 days of treatment $(\mathrm{t}=3.9, \mathrm{p}=0.002)$, according to the Oswestry Disability Index. We may draw a conclusion that the patient life quality improves due to the topical ketoprofen treatment.

The topical NSAIDs have been developed as a per os medication alternative. They are effective and may be used as first-line medication in case of a slight or moderate pain intensity. The mechanism of both forms is similar, while the potential of analgesic efficacy of the topical NSAIDs may compete with per os ones. The topical medications ensure the effective anesthetic concentrations at the sites of pain and inflammation, avoiding the systemic distribution at the physiologically active level [13]. The response rate in the group of topical NSAIDs was almost twice as high as in the per os NSAID group [14].

Comparative efficacy analysis of 9 topical NSAIDs available in the European Union (the gels of ketoprofen, diclofenac, piroxicam, niflumic acid and ibuprofen) demonstrated the most powerful anti-inflammatory effect for both ketoprofen forms. The cutaneous drug permeability was evaluated in vitro on mouse skin. The best transdermal

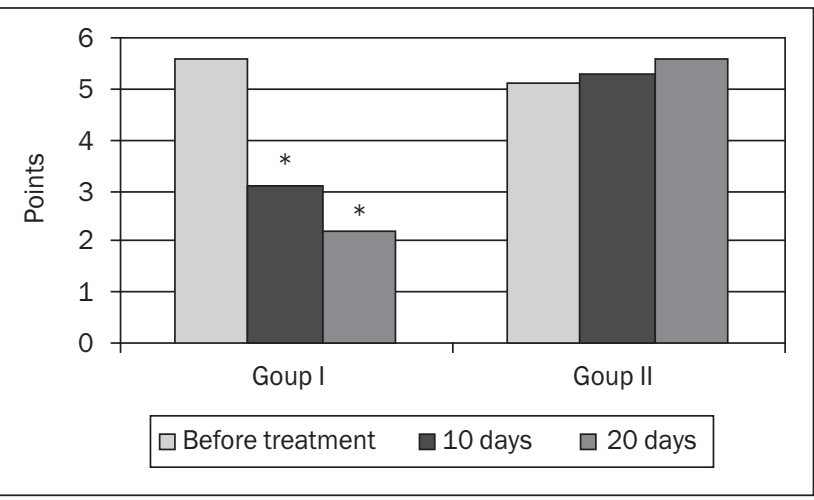

Fig. 4. The life quality parameters by EuroQol-5D scale on the ketoprofen treatment background Notes: ${ }^{*}-p<0.05$ compared to the initial values. 

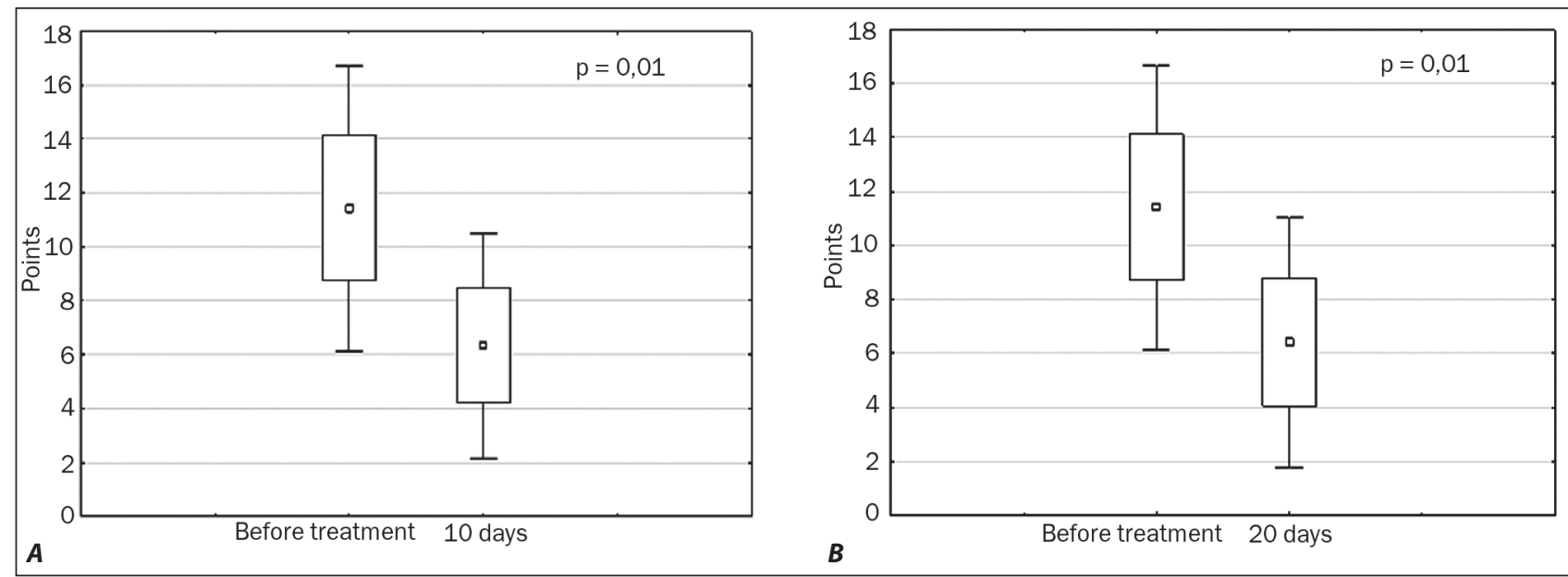

Fig. 5. The Tomayer test's dynamics before the treatment and 10 days $(A)$, 20 days after $(B)$ the ketoprofen therapy initiation
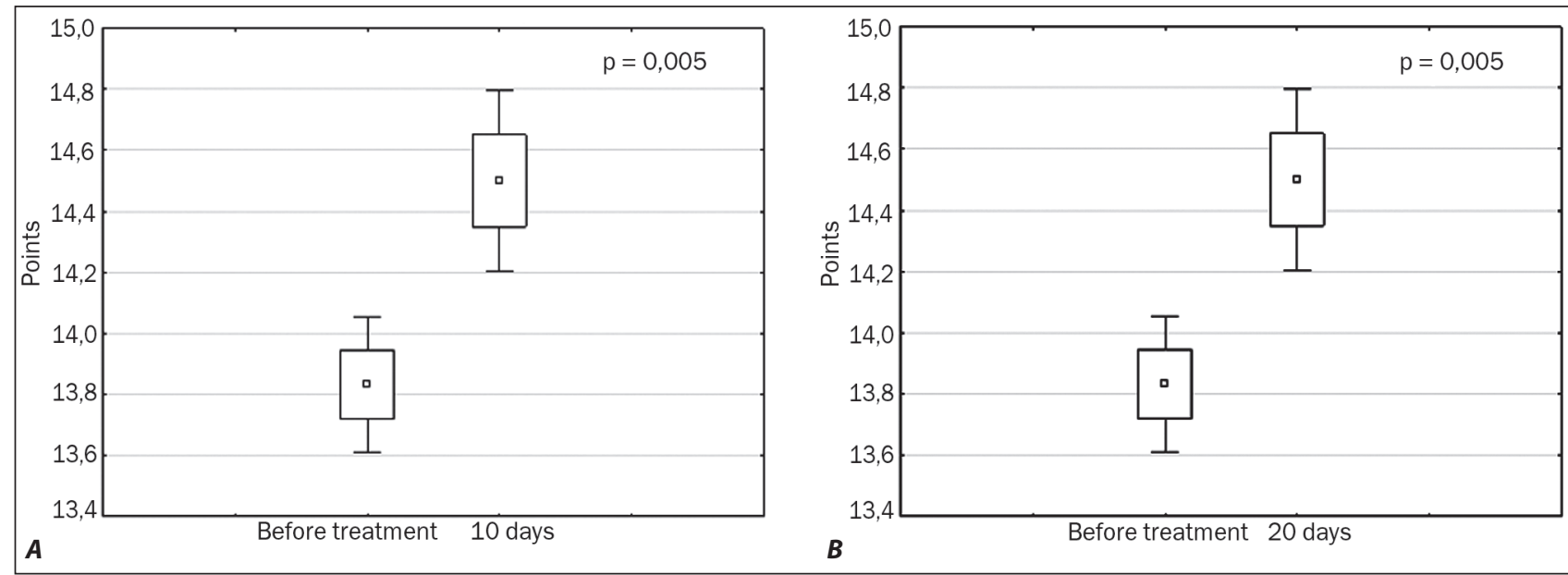

Fig. 6. The Schober test's dynamics before the treatment and 10 days $(A)$, 20 days after $(B)$ the ketoprofen therapy initiation

penetration was confirmed for the ketoprofen medications, explaining their high anesthetic activity [15].

The "Global Pain Faculty" roundtable participants have drawn the following conclusions: the topical NSAIDs are not associated with a higher frequency of localized adverse effects than placebo. In the acute and chronic pain studies, the topical NSAIDs are well tolerated and bring a minimum risk of systemic adverse effects. The highest efficacy of topical NSAIDs is observed in cases of pain occurring due to sports injuries and straining [6]. The ketoprofen gel is able to reach the highest local concentration in the tissues rather than in blood plasma [13].

Those participants using ketoprofen gel did not report any localized or systemic adverse effect. $75 \%$ of principal group and $33.3 \%$ of reference group evaluated the treatment efficacy as high.

\section{Conclusions}

The ketoprofen applications as a monotherapy significantly reduced the pain syndrome intensity and improved the functional abilities of patients suffering from the low back pain along with degenerative-dystrophic spinal changes. The absence of adverse effects emphasizes the high safety profile of the drug.

Conflicts of interests. Authors declare the absence of any conflicts of interests and their own financial interest that might be construed to influence the results or interpretation of their manuscript.

\section{References}

1. Deyo RA, Dworkin SF, Amtmann D, et al. Report of the NIH Task Force on research standards for chronic low back pain. Phys Ther. 2015 Feb;95(2):e1-e18. https://doi. org/10.2522/ptj.2015.95.2.e1.

2. Hartvigsen J, Hancock MJ, Kongsted A, et al. What low back pain is and why we need to pay attention. Lancet. 2018 Jun 9;391(10137):2356-2367. https://doi.org/10.1016/s01406736(18)30480-x.

3. Bozhenko NL. Backache: some aspects of diagnostics and treatment. Liky Ukrai'ny. 2015;(190):58-65. https://doi. org/10.37987/1997-9894.2015.4(190).207916. (in Ukrainian).

4. Kopchak OO. The problem of lower back pain taking into account evidence-based medicine data. Mezhdunarod- 
nyi Nevrologicheskii Zhurnal. 2020;16(3):41-49. https://doi. org/10.22141/2224-0713.16.3.2020.202769. (in Ukrainian).

5. Katić M, Svab I. Family Medicine. Zagreb: Medicinska naklada; 2017. 31-39 pp.

6. McMahon SB, Dargan P, Lanas A, Wiffen P. The burden of musculoskeletal pain and the role of topical non-steroidal anti-inflammatory drugs (NSAIDs) in its treatment. Ten underpinning statements from a global pain faculty. Curr Med Res Opin. 2021 Feb;37(2):287-292. https://doi.org/10.1080/030079 95.2020.1847718.

7. Verhagen AP, Downie A, Popal N, Maher C, Koes BW. Red flags presented in current low back pain guidelines: a review. Eur Spine J. 2016 Sep;25(9):2788-802. https://doi.org/10.1007/ s00586-016-4684-0.

8. Urits I, Burshtein A, Sharma M, et al. Low Back Pain, a Comprehensive Review: Pathophysiology, Diagnosis, and Treatment. Curr Pain Headache Rep. 2019 Mar 11;23(3):23. https://doi.org/10.1007/s11916-019-0757-1.

9. Back L, Urits I, Burshtein A, Sharma M, et al. Other Pain (A. Kaye and N. Vadivelu, Section Editors) and Treatment 2019:1-10. https://doi.org/10.1007/s11916-019-0757-1.

10. Witenko C, Moorman-Li R, Motycka C, et al. Considerations for the appropriate use of skeletal muscle relaxants for the management of acute low back pain. P T. 2014 Jun;39(6):427435 .
11. Stein H, Braun Y, Volpin G. Low back pain. Orthopedics. 2006 Mar;29(3):229-231. https://doi. org/10.3928/01477447-20060301-08.

12. Last AR, Hulbert K. Chronic low back pain: Evaluation and management. South African Fam Pract. 2010;52(3):184192. https://doi.org/10.1080/20786204.2010.10873969.

13. Breivik H, Collett B, Ventafridda V, Cohen R, Gallacher D. Survey of chronic pain in Europe: prevalence, impact on daily life, and treatment. Eur J Pain. 2006 May;10(4):287333. https://doi.org/10.1016/j.ejpain.2005.06.009.

14. Rafanan BS Jr, Valdecañas BF, Lim BP, et al. Consensus recommendations for managing osteoarthritic pain with topical NSAIDs in Asia-Pacific. Pain Manag. 2018 Mar;8(2):115128. https://doi.org/10.2217/pmt-2017-0047.

15. Derry S, Conaghan P, Da Silva JA, Wiffen PJ, Moore RA. Topical NSAIDs for chronic musculoskeletal pain in adults. Cochrane Database Syst Rev. 2016 Apr 22;4(4):CD007400. https://doi.org/10.1002/14651858.cd007400.pub3.

16. Komatsu T, Sakurada T. Comparison of the efficacy and skin permeability of topical NSAID preparations used in Europe. Eur J Pharm Sci. 2012 Dec 18;47(5):890-895. https:// doi.org/10.1016/j.ejps.2012.08.016.

Received 14.01.2021

Revised 13.02.2021

Accepted 26.02.2021

\footnotetext{
Information about authors

Vladyslav Povoroznyuk, Professor, Head of Department of clinical physiology and pathology of musculo-skeletal system, State Institution "D.F. Chebotarev Institute of Gerontology of the NAMS of Ukraine", Kyiv, Ukraine; https://orcid.org/0000-0002-8855-482X

Anna Musiienko, PhD, Junior Research Fellow at the Department of clinical physiology and pathology of musculo-skeletal system, State Institution“D.F. Chebotarev Institute of Gerontology of the NAMS of Ukraine", Kyiv, Ukraine; http://orcid.org/0000-0002-1672-1991

Nataliia Zaverukha, Junior Research Fellow at the Department of Clinical Physiology and Pathology of musculoskeletal system, State Institution "D.F. Chebotarev Institute of Gerontology of the NAMS of Ukraine", Kyiv, Ukraine; https://orcid.org/0000-0002-0181-2794

Alla Tkachuk, laboratory assistant of the first category of the Department of clinical physiology and pathology musculoskeletal system, State Institution “D.F. Chebotarev Institute of Gerontology of the NAMS of Ukraine", Kyiv, Ukraine
}

Поворознюк В.В., Мусієнко А.С., Заверуха Н.В., Ткачук А.А.

ДУ «Інститут геронтології імені Д.Ф. Чеботарьова НАМН України», Український науково-медичний центр проблем остеопорозу, м. Київ, Україна

\section{Ефективність та безпечність лікування препаратом Фастум' гель у хворих із болем у нижній ділянці спини}

Резюме. Метою дослідження було вивчення ефективності й безпечності терапії препаратом Фастум ${ }^{\circledR}$ гель у хворих із болем у нижній ділянці спини (БНДС) на тлі дегенеративно-дистрофічних змін хребта. Матеріали та методи. Обстежені 24 особи чоловічої та жіночої статі віком 50-69 років із БНДС тривалістю понад 14 діб із подальшим розподілом на дві групи. Група I - 12 пацієнтів, які застосовували кетопрофен у вигляді аплікацій тонким шаром на поперекову ділянку 2 рази на добу протягом 10 діб. Група II - 12 пацієнтів, яким проводили аплікації вазеліну тонким шаром на ту ж ділянку 2 рази на добу протягом 10 діб. Пацієнти застосовували досліджувані препарати як монотерапію. Обстеження проводили перед початком терапії й на 10 -ту і 20 -ту добу лікування. Результати. У пацієнтів, які застосовували аплікації з кетопрофеном, вірогідно знижувалась інтенсивність болю за всіма чотирма складовими візуально-аналогової шкали та опитувальником Роланда - Морріса. Водночас вірогідно покращува- лися функціональні можливості за результатами тесту Шобеpa $(\mathrm{t}=3,54, \mathrm{p}=0,005)$ й Томаєра $(\mathrm{t}=3,08, \mathrm{p}=0,01)$. Показники якості життя відповідно до шкали EuroQul-5D в пацієнтів, які застосовували локальну форму кетопрофену, вірогідно поліпшилися на $45 \%(\mathrm{t}=4,19, \mathrm{p}=0,002)$, а життєдіяльність за результатами анкети Освестрі - на 39,3\% через 10 діб лікування $(\mathrm{t}=3,9, \mathrm{p}=0,002) .75 \%$ пацієнтів основної групи й 33,3 \% групи порівняння оцінили ефективність лікування як високу за індексом Лікерта. В обох групах не був зареєстрований жодний локальний і системний побічний ефект. Виснов$\boldsymbol{\kappa} \boldsymbol{u}$. Застосування монотерапії кетопрофеном гелем вірогідно знижувало інтенсивність больового синдрому й поліпшувало функціональні можливості хворих із БНДС. Відсутність побічних ефектів при лікуванні препаратом свідчить про його високий профіль безпечності для пацієнтів.

Ключові слова: біль у нижній ділянці спини; локальна форма; кетопрофен гель 
Поворознюк В.В., Мусиенко А.С., Заверуха Н.В., Ткачук А.А.

ГУ «Институт геронтологии имени Д.Ф. Чеботарева НАМН Украины», г. Киев, Украина

\section{Эффективность и безопасность лечения препаратом Фастум ${ }^{\circledR}$ гель у лиц с болью в нижней части спины}

Резюме. Целью исследования было изучение эффективности и безопасности терапии препаратом Фастум ${ }^{\circledR}$ гель у лиц с болью в нижней части спины (БНЧС) на фоне дегенеративно-дистрофических изменений позвоночника. Материалы u методы. Обследованы 24 человека мужского и женского пола в возрасте 50-69 лет с БНЧС продолжительностью более 14 дней с последующим делением на две группы. Группа I - 12 пациентов, получавших кетопрофен в виде аппликаций тонким слоем на поясничную область 2 раза в сутки в течение 10 дней. Группа II - 12 пациентов, которым проводили аппликации вазелина тонким слоем на тот же участок 2 раза в сутки в течение 10 дней. Пациенты применяли исследуемые препараты в качестве монотерапии. Обследование проводили перед началом терапии и на 10-й и 20-й день лечения. Pезультаты. У пациентов, получавших аппликации кетопрофеном, достоверно снижалась интенсивность боли по четырем составляющим визуально-аналоговой шкалы и опроснику Роланда - Морриса. Вместе с этим достоверно улучшались функциональные возможности согласно результатам теста Шобера $(\mathrm{t}=3,54, \mathrm{p}=0,005)$ и Томайера $(\mathrm{t}=3,08$, $\mathrm{p}=0,01)$. По результатам шкалы EuroQul-5D показатели качества жизни у пациентов, применявших локальную форму кетопрофена, достоверно улучшились на $45 \%(\mathrm{t}=4,19$ $\mathrm{p}=0,002)$, на $39,3 \%$ согласно анкете Освестри через 10 суток лечения $(\mathrm{t}=3,9, \mathrm{p}=0,002) .75 \%$ пациентов основной группы и 33,3 \% группы сравнения оценили эффективность лечения как высокую согласно индексу Ликерта. В обеих группах не было зарегистрировано ни одного локального и системного побочного эффекта. Bыводы. Кетопрофен гель в виде монотерапии достоверно снижал интенсивность болевого синдрома и улучшал функциональные возможности больных с БНЧС. Отсутствие побочных эффектов при лечении препаратом свидетельствует о его высоком профиле безопасности для пациентов.

Ключевые слова: боль в нижней части спины; локальная форма; кетопрофен гель 